\title{
Intralesional epidermal growth factor application is a potential therapeutic strategy to improve diabetic foot ulcer healing and prevent amputation
}

\author{
Ömer Arda Çetinkaya ${ }^{1}\left(\right.$ ID), Süleyman Utku Çelik²(ID), Miraç Barış Erzincan (ID), Barış Hazır ${ }^{1}$ (ID), Hakan Uncu'(ID) \\ 1 Department of General Surgery, Ankara University School of Medicine, Ankara, Turkey \\ ${ }^{2}$ Clinic of General Surgery, Gulhane Training and Research Hospital, Ankara, Turkey
}

\begin{abstract}
Objective: This study aimed to investigate the efficacy of intralesional epidermal growth factor (EGF) in preventing the extremity from a major amputation and its effects on wound healing in chronic diabetic foot ulcers (DFUs).

Material and Methods: Thirty-three patients with DFUs were treated with intralesional EGF application between January 2013 and January 2017. The first endpoint was to determine the prevention rate of major amputation within 12 months following treatment. The second endpoints were the recovery of ulcer surface area with $\geq 50 \%$ granulation following two months and the healing of ulcer surface area with $\geq 75 \%$ granulation following six months after the first application of EGF.

Results: After three patients were excluded because of major side effects in the remaining 30 patients (48 DFUs), granulation rate of $\geq 50 \%$ was achieved in 24 (37 DFUs) patients, and not achieved in 6 (11 DFUs) patients eight weeks following the EGF application. A granulation rate of $\geq 75 \%$ was achieved in 21 (31 DFUs) patients after six months. At 12 months following the treatment, one major and seven minor amputations were performed, a total of $10 \mathrm{DFUs}$ in five patients were not healed, and the DFUs in 17 patients completely recovered.

Conclusion: Intralesional EGF application has positive results in addition to good foot care in DFUs, and promising results can be obtained by protecting the extremity from amputation by using it in patients whose vascular intervention methods are not appropriate and have DFUs that do not heal with conventional wound care treatments.
\end{abstract}

Keywords: Amputation, diabetic foot ulcer, epidermal growth factor

Cite this article as: Çetinkaya ÖA, Çelik SU, Erzincan MB, Hazır B, Uncu H. Intralesional epidermal growth factor application is a potential therapeutic strategy to improve diabetic foot ulcer healing and prevent amputation. Turk J Surg 2020; 36 (1): 15-22.

Corresponding Author

Ömer Arda Çetinkaya

E-mail: omerardacetinkaya@yahoo.com

Received: 29.05.2019

Accepted: 27.08.2019

Available Online Date: 18.03.2020

( Copyright 2020 by Turkish Surgical Society Available online at www.turkjsurg.com

DOI: 10.5578/turkjsurg.4541

\section{INTRODUCTION}

The prevalence of type 2 diabetes in the world is higher than expected and continues to rise in all regions. The main reasons for this rise are aging in the world population, economic developments, the proliferation of sedentary lifestyles, and the increase in obesity due to unhealthy food consumption (1). In 2017, there were 425 million diabetic patients in the world, and it is estimated that this number will reach 629 million with a 48\% increase in 2045. In addition, there were 58 million diabetic patients which accounts for $8.8 \%$ of the population aged 20-79 in the European region whereas, it is estimated that this number will reach 67 million with a 16\% increase. Moreover, total healthcare expenditure on diabetes was estimated to be 727 billion dollars (20-79 years) worldwide in 2017 (2).

Diabetic foot is a serious chronic complication consisting of lesions in deep tissues related to peripheral neuropathy and peripheral vascular disease. Its incidence has increased due to the increasing prevalence of diabetes and the prolonged life expectancy in diabetic patients. Diabetic foot ulcer (DFU) is a disease difficult to diagnose and treat and does not improve even with the newest treatment methods used in modern medicine. In diabetic patients, the risk of developing ulcers in lower extremities is 15\% during the course of diabetes (3). Besides, amputation rate increases 10-20 times in diabetic patients compared to non-diabetics and the risk of mortality in the first 5 years in patients that underwent lower extremity amputation is nearly $40 \%(4,5)$.

In patients with DFU, health expenditures are 5 times higher than diabetic patients without foot ulcers. In 2007, one-third of the expenditures related to diabetes were 
made to DFUs. In addition, expenditures for the treatment of high-grade foot ulcers are 8 times higher than those with lower grades (6). The incidence of DFU in diabetic patients is $2 \%$ in high-income countries, and DFU is the most common cause of non-traumatic amputation and 1\% of diabetic patients undergo low extremity amputations. These rates are higher in middleand low-income countries. Considering this data, it is understood that the number of patients with DFU will increase in the upcoming period and we will continue to fight with this disease. However, DFU often does not respond to conventional and new treatment methods. Unsuccessful results lead to the amputation of the extremity with DFU $(3,7)$.

Main points in the management of DFU are metabolic control, treatment of comorbidities, revascularization, antimicrobial treatment of infections and off-loading the pressure on the wound. In local wound treatment, aggressive debridement, wound dressings with moist healing and bacterial control; and if necessary, advanced treatments such as growth factors and skin produced by tissue engineering can be used (8-13). However, in some cases, the effects of these treatment modalities on clinical practice do not meet the expectations of clinical trials (14).

The healing process of DFU is prevented by local factors affecting all phases of recovery, such as abnormal neutrophil function in the late repair phase, defective fibroblast activity, poor angiogenesis, and lack of cell migration $(15,16)$. Recombinant human epidermal growth factor (rhEGF) is a polypeptide consisting of 53-amino acids, which was isolated from submaxillary glands of rats by Stanley Cohen and Rita Levi-Montalcini in 1962 using DNA technology, which earned them the Nobel Physiology and Medicine Award in 1986 (17). This molecule acts by stimulating extracellular matrix formation, cellular proliferation, and angiogenesis and causes proliferation of fibroblasts, keratinocytes, and vascular endothelial cells (18-20). Its effect mechanism is based on the interaction of specific epidermal growth factor receptor (EGFr) with tyrosine kinase activity (21). Most of these receptors have been reported in human tissue. The rational justification for using rhEGF to treat DFU is mainly based on the reversal of the existing recovery disorder in patients with diabetes, especially the lack of growth factors in the wound area. rhEGF stimulates healing and angiogenesis and protects cells from oxidative and ischemia-reperfusion injury (20-22).

Some clinical studies have been conducted to evaluate the efficacy of topical administration of rhEGF in different indications such as radiogenic ulcers, venous ulcers, and burns (23-25). To obtain adequate activity, growth factor must be present in deeper layers of the wound. This may be limited in topical formulations because the diffusion of the active substance is affected by necrotic tissue, sepsis, inflammation, and wound proteases (25). However, intralesional injection of the growth factor may bring the active substance to the desired site. Therefore, we aimed to investigate the effectiveness of EGF application in the direction of protecting the extremity from the major amputation in this study.

\section{MATERIAL and METHODS}

\section{Patients}

Thirty-three patients who underwent intralesional EGF application for DFUs admitted to Ankara University School of Medicine, Department of General Surgery, Wound Care Unit between January 2013 and January 2017 were included into this study. Data from a prospectively collected database of patients having DFU, who failed to heal even after three months of conventional wound therapy, were retrospectively analyzed. The study included patients over 18 years of age with advanced DFUs, which failed to heal even after conventional wound treatment methods with a high risk of amputation. There was no distinction between the topographic location of the wound in the lower extremity.

Patients with necrotic tissue and/or advanced/non-treatable osteomyelitis in DFU, patients who were eligible for revascularization in DFU treatment according to clinical and radiological evaluations, patients with a history of malignancy, radiotherapy, sepsis, or known allergies to rhEGF, and patients who did not wish to participate in the study were excluded. Patients with renal or liver failure and patients who used immunosuppressive treatment or corticosteroids were also not included in the study. All patients were informed about the aim and methods of the research both verbally and in written form; written consent was also obtained from the patients before the completion of study measurement. The study protocol was approved by a local ethics committee (03-153-18) and was conducted following the Declaration of Helsinki.

\section{Treatment Protocols}

All patients were hospitalized during their treatment. Patients received severe glycemic control, and were treated for their comorbidities, and in patients who were eligible for revascularization, rhEGF (Heberprot-P®, Has Biotech, Turkey) was started afterward. In the local treatment of ulcers, adequate debridement was performed, and necrotic tissues were removed. Toe amputation, and if necessary, metatarsophalangeal amputation was performed when the toes were necrosed and then rhEGF was applied. Antimicrobial treatment of the infections was provided by appropriate local and systemic antibiotics according to tissue culture results and antimicrobial dressings were used when necessary. Before rhEGF administration, all ulcers were cleared of infection, which was proven by tissue cultures. Pressure reduction (off-loading) on the wound was ensured by bed rest, the use of a walker and, if necessary, performing an off-loading plaster.

While applying rhEGF to DFU, injectors with $75 \mu \mathrm{g}$ of rhEGF diluted in $5 \mathrm{~mL}$ saline were prepared. rhEGF was injected into the 
wound and to its peripheral tissue starting from deep layers in DFU that had been cleaned of dead tissues (with appropriate antibiotics if infected) before. Applications continued 3 days per week consecutively until full wound healing was achieved, or 8 weeks of treatment was done (a maximum of 24 doses). Treatment was stopped when successful healing tissue was obtained or the wound was completely closed or the wound area was less than $1 \mathrm{~cm}^{2}$ with granulation. The safety of rhEGF was checked by symptoms and physical examination at each visit. Local and systemic side effects of rhEGF were classified as mild, moderate, severe, and very serious.

\section{Follow-up}

Diabetic scar ulcers of the patients were measured every two weeks before, during and after rhEGF treatment. Wound length, width, and depth were recorded using a measuring scale. For digital image analysis, standard photographs were taken by placing the scale on the border of the wound. The ulcer areas were measured in square centimeter $\left(\mathrm{cm}^{2}\right)$ by measuring the longest width and length of the ulcer after debridement. Recurrence and other long-term side effects were also checked during the follow-ups in the first year after the end of rhEGF treatment.

\section{Outcome}

The first endpoint of the study was to show that the extremity was rescued from major amputation within 12 months following the end of the treatment. The second endpoints of the study were the recovery of ulcer surface area with $\geq 50 \%$ granulation tissue two months after the first application of rhEGF and the healing of ulcer surface area with $\geq 75 \%$ granulation tissue six months after the first application.

\section{Statistical Analysis}

Data were expressed as mean \pm standard deviation and range for continuous variables and frequency for categorical variables. All statistical data were analyzed with the use of Statistical Package for the Social Sciences version 16.0 for Windows (SPSS, Chicago, IL).

\section{RESULTS}

Thirty-five lower extremities were treated in 33 patients (24 male and 9 female) with a mean age of 61.7 years. Of the patients, $42.4 \%(n=14)$ had a history of smoking with an average of 31.3 pack-years. Concomitant comorbidities were hypertension (81.8\%), peripheral arterial disease (81.8\%), atherosclerotic heart disease (57.5\%), hyperlipidemia (30.3\%), chronic kidney disease $(21.2 \%)$, and chronic liver failure (9.1\%). Only $12.1 \%(n=4)$ of the patients did not have comorbidities. Mean duration of diabetes mellitus was $20.5 \pm 10.5$ years and the average $\mathrm{HbA} 1 \mathrm{c}$ was $8.4 \pm$ 3.6. Vast majority of the patients (81.8\%) were using insulin therapy and the mean duration of insulin use was $12.1 \pm 7.9$ years. Ankle-brachial index (ABI) could not be evaluated in 6 lower ex- tremities; mean ABI of the 29 extremities was $0.81 \pm 0.18$. Table 1 shows the baseline demographic and clinical characteristics of the patients.

A total of 52 DFUs in 35 lower extremities of 33 patients were treated. Mean size of the ulcers was $26.8 \pm 6.1 \mathrm{~cm}^{2}$. Foot ulcer was divided into three severity-level categories according to Wagner ulcer classification system (26): grade 3 (33 ulcers, 63.5\%), grade 2 (2 ulcers, 3.8\%), and grade 1 (17 ulcers, 32.7\%). 32.6\% ( $n=17)$ of the DFUs were on the amputation stump, $21.1 \%(n=11)$ were on the foot dorsum, 19.2\% ( $n=10)$ were on the heel, 17.3\% ( $n=9)$ were in the plantar region, and $9.8 \%(n=5)$ were in other regions. In addition to conventional wound care methods, negative pressure wound therapy (NPWT) was performed in 54.5\% ( $n=18)$ of the patients, antibacterial passive wound care coverings were

Table 1. Demographics and the clinical characteristics of the patients

\begin{tabular}{|c|c|}
\hline Characteristics & \\
\hline Number of patients & 33 \\
\hline Number of low extremities & 35 \\
\hline Number of DFUs & 52 \\
\hline Gender (female/male) & $9 / 24$ \\
\hline Age (years) & $61.7 \pm 12.1$ \\
\hline \multicolumn{2}{|l|}{ Smoking history } \\
\hline Positive history & $11(42.4 \%)$ \\
\hline Mean package-year & $31.3 \pm 18.6$ \\
\hline \multicolumn{2}{|l|}{ Comorbidities } \\
\hline Hypertension & $27(81.8 \%)$ \\
\hline PAD & $27(81.8 \%)$ \\
\hline ASHD & $19(57.5 \%)$ \\
\hline Hyperlipidemia & $10(30.3 \%)$ \\
\hline CKD & $7(21.2 \%)$ \\
\hline CLD & $3(9.1 \%)$ \\
\hline Duration of diabetes (years) & $20.5 \pm 10.5$ \\
\hline HbA1c (\%) & $8.4 \pm 3.6$ \\
\hline \multicolumn{2}{|l|}{ Wagner ulcer classification } \\
\hline Grade 1 & $2(3.8 \%)$ \\
\hline Grade 2 & $17(32.7 \%)$ \\
\hline Grade 3 & $33(63.5 \%)$ \\
\hline \multicolumn{2}{|l|}{ Location of ulcers } \\
\hline Amputation stump & $17(32.7 \%)$ \\
\hline Foot dorsum & $11(21.2 \%)$ \\
\hline Heel & $10(19.2 \%)$ \\
\hline Plantar region & $9(17.3 \%)$ \\
\hline Others (toe, medial malleolus etc.) & $5(9.6 \%)$ \\
\hline
\end{tabular}

DFU: Diabetic foot ulcer, PAD: Peripheral arterial disease, ASHD: Atherosclerotic heart disease, CKD: Chronic kidney disease, CLD: Chronic liver disease. 
used in 21.2\% ( $n=7)$ and grafting with cellutone method was performed in $9.1 \%(n=3)$.

The most common minor side effects were local burning and pain. Patients with minor side effects were treated with antihistamines, analgesics, and antiemetics if necessary. Despite minor reactions, rhEGF administration was continued. Anaphylactic reaction developed in one patient after the first administration of rhEGF and in another patient after the second administration of rhEGF. In one patient, syncope developed in the $5^{\text {th }}$ session of rhEGF administration. These three patients were excluded from the study because of major drug side effects. In the remaining 30 (48 DFUs) patients, an average granulation rate of $72.2 \%$ was obtained after 8 weeks of treatment (Figure 1).
After eight weeks, which was the second endpoint of our study, granulation rate of 50\% and above was achieved in 24 (37 DFUs) patients (Figure 2), and not achieved in 6 (11 DFUs) patients. In 21 (31 DFUs) of the 24 (37 DFUs) patients who had a granulation rate of $50 \%$ or more after eight weeks, a granulation rate of $75 \%$ or more was achieved after six months. Twenty-three of the 31 DFUs were fully healed and epithelialized, in 8 of them, wound size significantly decreased and granulation rate was above 95\%. At 1-year follow-up of these 21 patients, 17 had no recurrence of ulcers, 4 of the patients had recurrent ulcers and three had toe amputation and one of them underwent a below-knee amputation. In the remaining 3 (6 DFUs) patients, granulation could not be ensured at $75 \%$ or more at six months despite $50 \%$ or more granulation at the $8^{\text {th }}$ week. Although no improvement
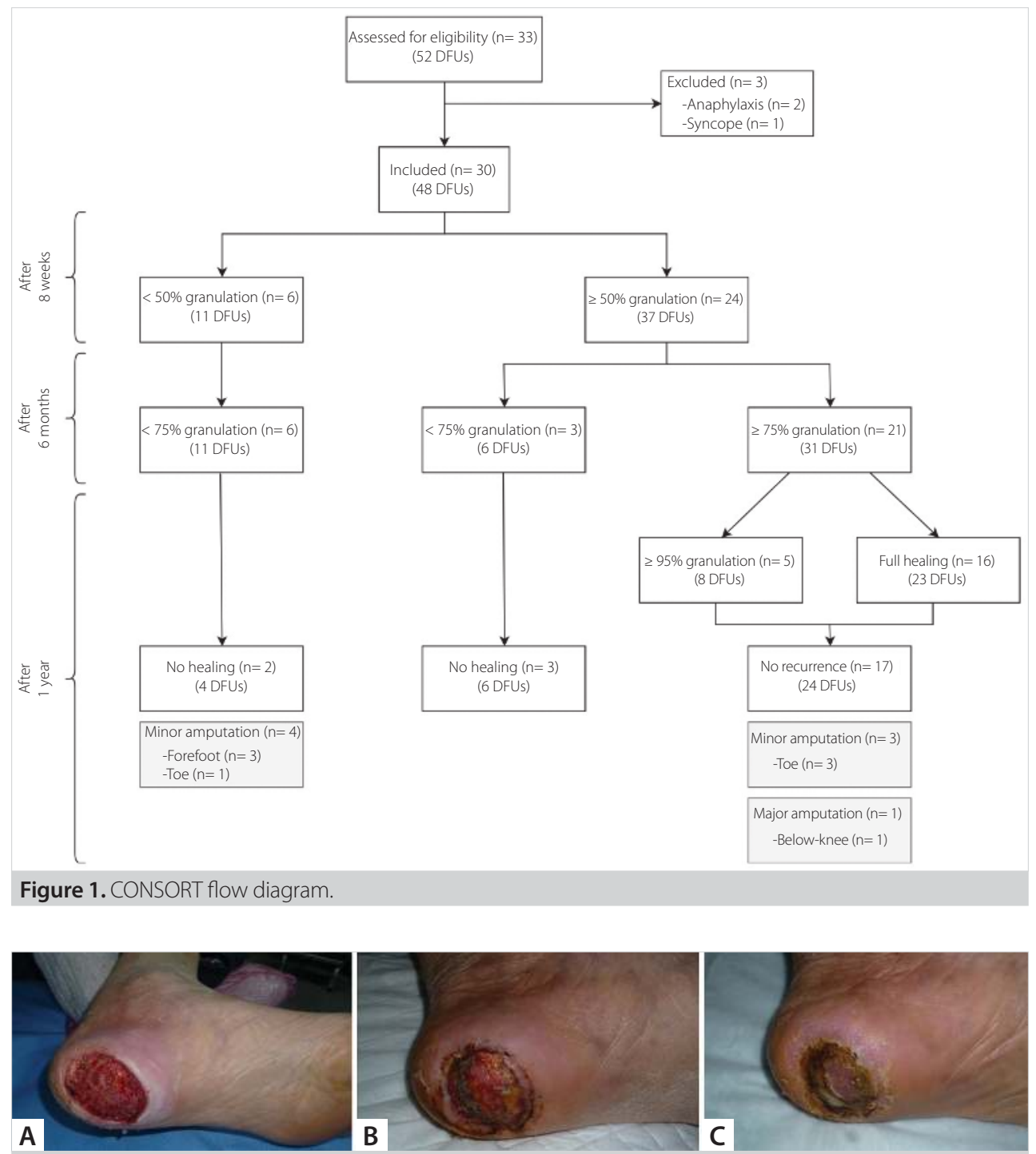

Figure 2. Chronological evoluation of a diabetic foot ulcer classified as Wagner grade 2 of a 55 -years-old female. A. Initial appearance of the ulcer; $\mathbf{B}$. A granulation rate of $\geq 50 \%$ (eight weeks after intralesional epidermal growth factor application), C. $\geq 95 \%$ granulation rate six months after the initial treatment. 
was observed in the ulcers at the 1-year follow-up of these patients, they did not progress to amputation.

In 6 (11 DFUs) patients who did not have granulation of 50\% or more after eight weeks, the rate of granulation was less than $75 \%$ at the end of 6th month. Despite rhEGF treatment in four of these patients, no improvement could be achieved and three had an amputation of the forefoot and one had an amputation of the toe. There was no improvement in the remaining two patients.

The second endpoint of our study was achieved in a total of 21 patients with a granulation rate of $75 \%$ and above after six months. The first endpoint of our study was the recovery of the extremity from major amputation within 12 months following the treatment and it was achieved in all patients except for one. In one patient, DFU recovered after rhEGF administration and even though the wound was completely closed after 14 weeks, it recurred in the same localization nine weeks after recovery. Despite all treatments, there was no improvement in the wound and the patient had to undergo a below-knee amputation. Except for this patient, minor amputation was performed in the lower extremity of seven patients in the first year. In three of them, even though the wound size decreased and more than 95\% granulation tissue was formed and then complete recovery was achieved, the ulcers had progressed by recurrence and resulted in a toe amputation. In the remaining four patients, no improvement could be achieved and three had anterior foot amputation and one had toe amputation.

\section{DISCUSSION}

Several studies have suggested that growth factors and rhEGF contribute positively to wound healing. rhEGF stimulates epidermal repair in animal excisional and thermal injury models and may also stimulate dermal repair (27). In a study using wound model on pigs, Nanney et al. have found that there was an increase in the thickness of granulation tissue depending on the rhEGF dose and reported the relationship between rhEGF and epithelization (28). Cooper et al. have shown that some growth factors were significantly reduced in chronic wound fluid compared to acute wounds (29). In their meta-analysis, Zhang et al. have found that the addition of growth factors to standard wound care in partial-thickness burns was effective and safe (30). In a Cochrane systematic review by Marti-Carvajal et al., it has been shown that growth factors would increase the chance of complete healing of foot ulcers in patients with diabetes (31). Gomez-Villa et al. have also indicated that patients with DFU who received intralesional rhEGF was achieved more complete wound healing compared to standard wound care patients and rhEGF promoted epithelization of the wound bed and significantly reduced the area of treated ulcer (32).

As a result of our study, we observed that 29 of 30 patients with DFU who had undergone rhEGF treatment were rescued from major amputation. The ulcers completely healed in 21 patients and most of them (80.9\%) did not recur. However, four of the 21 cases recurred within one year after treatment and three of them progressed minor amputations and in one patient the ulcer recurred after nine weeks and progressed to a below-knee amputation. As no adequate granulation was achieved, DFUs did not heal in nine patients in the one-year follow-up period. It was seen that the ulcers of five patients did not progress to any amputation, and in four patients ulcers progressed further to minor amputation. The most important result of our study, in DFUs where the known treatment methods had failed before, intralesional rhEGF application was an effective and reliable treatment that protected the extremity from major amputation. In contrast to other studies, $81.8 \%$ of the patients had peripheral arterial disease, $57.5 \%$ atherosclerotic heart disease, and $21.2 \%$ chronic kidney disease. Besides, $63.5 \%$ of the ulcers were grade 3 and $32.6 \%$ were located on the amputation stump. Although the rate of major amputation was low in our study, we thought that the high minor amputation and non-healing ulcer ratio were due to these reasons.

All patients in the study were hospitalized, their metabolic control was improved, and comorbidities were treated. Before rhEGF treatment was applied, tissue culture was taken from all patients' DFUs and then surgical debridement was performed and necrotic tissues and fibrins on the wound were removed. Wounds were washed with saline and when necessary, antibacterial passive wound dressings and NPWT were applied. According to the results of tissue cultures, appropriate local and systemic antibiotics were used and rhEGF treatment was started only when there was no reproduction in the tissue culture. Pressure reduction (off-loading) on the wound was ensured by bed rest, use of walkers and off-loading plaster when necessary. Despite all these treatments and rhEGF treatment, seven patients had to undergo minor amputation and one patient had to undergo major amputation.

In the study by Kahraman et al. evaluating long-term results of 34 patients with DFU undergoing intralesional rhEGF, patients received an average of 18 doses of rhEGF (33). In the five-year follow-up, four patients died due to diabetic complications. Of the remaining 29 patients, 27 had no recurrence of ulcers, while 1 had first toe amputation due to ischemic necrosis. In another study with 17 patients, complete wound closure was achieved in 16 of the patients, and only one patient had a recurrence of ulcers at 1-year follow-up (34). In a randomized controlled trial of hEGF-containing cream in 61 patients with DFU, Tsang et al. have randomly divided patients into three groups to investigate the effect of hEGF on healing (35). The first group was placebo, the second group was treated with low-dose hEGF containing cream, and the third group was treated with high-dose hEGF containing cream. As a result of the study, it was seen that com- 
plete recovery rate was higher and recovery time was shorter in the third group compared to other groups. There was no significant difference in healing time between the placebo group and low-dose hEGF group. Therefore, the authors linked dose sensitivity to the need for continuous hEGF in wound healing and the dose-dependent effect of rhEGF on granulation tissue formation. They also thought that the threshold value required to show the therapeutic effect of hEGF could be influenced by the presence of growth factor inhibitors or proteases in the microenvironment of the wound, or that higher levels of rhEGF would increase other cytokine levels needed to heal the wound. In a phase 3 study published by Park et al., it has been suggested that $0.005 \%$ rhEGF administered in topical spray form had a faster recovery process and a higher complete recovery rate than the placebo group, regardless of $\mathrm{HbA} 1 \mathrm{c}$ level (36). Yang et al. have reported that topically administered rhEGF had a statistically significant higher complete cure rate than the control group in their meta-analysis with data from four randomized controlled trials involving 294 patients (37). Acosta et al. have applied 25 micrograms of rhEGF to 29 patients with Wagner grade 3 to 4 DFUs or amputation stump ulcers three times per week (9). As a result of the study, the desired granulation level was reached in $86 \%$ of the patients in the eighth application, and 17 patients were rescued from amputation and only one of these patients had a recurrence. In a study by Romero Prada et al. comparing rhEGF administration and conventional treatment; in the rhEGF-treated group, the number of amputations was lower, survival was longer, and rhEGF was cost-effective (38). In a study by Fernandez-Montequin et al. performed in patients with Wagner grade 3-4 diabetic ulcer patients with $25 \mathrm{mg}$ rhEGF, 75 mg rhEGF, and a control group; complete granulation response and wound closure rate were the lowest in the control group and highest in the $75 \mathrm{mg}$ rhEGF group and the time to reach complete granulation was the longest in the control group and the shortest in the $75 \mathrm{mg}$ rhEGF group (39). As a result of the study, rhEGF was shown to increase the dose-dependent effect of ulcer healing. Aktas et al. have conducted a study investigating the efficacy of intralesional rhEGF in saving the extremity from amputation in DFUs with ischemic components (40). Although the patients included in this study had previously a revascularization, NPWT, and standard wound care treatments, there was not enough healing in DFUs. In these patients who were suggested to undergo amputation as a last option, intralesional rhEGF treatment was applied and 9 of 11 patients were rescued from amputation. However, topical rhEGF formulas have significant advantages over intralesional formulas in terms of ease of use and accessibility. In our study, to avoid growth factor inhibitors and proteases and to bring the active agent into the desired region, and therefore to gain maximum effects of the growth factor, intralesional injection of rhEGF was administered.
Peripheral artery disease (PAD) is one of the well-known risk factors for the progression of DFUs to amputation $(9,40)$. In our study, PAD was present in nearly $80 \%$ of the patients in whom we could complete rhEGF treatment and these patients did not have any chance of revascularization. In our study, we think that the high rate of non-healing ulcers and minor amputations was because of the high prevalence of PAD as a concomitant disease. Another finding of our study was that patients with a granulation rate of $<50 \%$ after eight weeks and those with $<75 \%$ granulation after six months failed to achieve complete healing at the end of one-year follow-up. This showed us that the healing in the early period was an important parameter to predict the complete healing of a DFU in patients treated with rhEGF.

There are several limitations to our study. First, the small size of our sample and the lack of our control group limited the reliability of the study. Secondly, DFUs of different localization originate from different etiologies, so recovery rates and durations will be different. In our study, our patients'DFUs were in different localizations and we could not establish a standard in this regard. Thirdly, our retrospective study will be supported by prospective studies and more reliable results will be achieved. Finally, this is a single-center study and multicenter studies should be supported.

\section{CONCLUSION}

Intralesional growth factor application had positive results in addition to good foot care in DFUs ranging from grade 1 to 3 according to Wagner classification. Promising results can be obtained by protecting the extremity from major amputation by using intralesional growth factor in DFUs which are not suitable for vascular intervention methods and not healing with conventional wound care treatments. Further study is required to define the optimal dose of rhEGF, the frequency of optimal administration, and potential rhEGF interaction with other growth factors such as PDGF in enhancing the healing of the wound. In the future, it is also important to examine the cost effects in terms of wound healing and amputation prevention.

Ethics Committee Approval: The study protocol was approved by a local ethics committee (03-153-18) and was conducted following the Declaration of Helsinki.

Informed Consent: Written informed consent was obtained from patients who participated in this study.

Peer-review: Externally peer-reviewed.

Author Contributions: Concept - Ö.A.Ç., H.U.; Design - Ö.A.Ç., S.U.Ç., H.U.; Supervision - Ö.A.Ç., S.U.Ç.; Resource - Ö.A.Ç., H.U.; Materials - Ö.A.Ç., S.U.Ç., M.B.E., B.H., H.U.; Data Collection and/or Processing - S.U.Ç., M.B.E., B.H.; Analysis and Interpretation - Ö.A.Ç., S.U.C.; Literature Review - M.B.E., B.H.; Writing Manuscript - Ö.A.Ç, S.U.C., M.B.E., B.H.; Critical Reviews - Ö.A.Ç, S.U.Ç.

Conflict of Interest: The authors have no conflicts of interest to declare.

Financial Disclosure: The authors declared that this study has received no financial support. 


\section{REFERENCES}

1. Basu S, Yoffe P, Hills N, Lustig RH. The relationship of sugar to population-level diabetes prevalence: an econometric analysis of repeated cross-sectional data. PLoS One 2013;8:e57873. [CrossRef]

2. International Diabetes Federation. IDF Diabetes Atlas, $8^{\text {th }}$ edn. Brussels, Belgium: International Diabetes Federation, 2017. Available from: http://www.diabetesatlas.org. [CrossRef]

3. Singh N, Armstrong DG, Lipsky BA. Preventing foot ulcers in patients with diabetes. JAMA 2005;293:217-28. [CrossRef]

4. Moxey PW, Gogalniceanu P, Hinchliffe RJ, Loftus IM, Jones KJ, Thompson $M M$, et al. Lower extremity amputations-a review of global variability in incidence. Diabet Med 2011;28:1144-53. [CrossRef]

5. Bakker K, van Houtum WH, Riley PC. 2005: The International Diabetes Federation focuses on the diabetic foot. Curr Diab Rep 2005;5:436-40. [CrossRef]

6. Driver VR, Fabbi $M$, Lavery $L A$, Gibbons $G$. The costs of diabetic foot: the economic case for the limb salvage team. I Vasc Surg 2010;52(Suppl):S17-S22. [CrossRef]

7. Apelqvist J, Bakker K, van Houtum WH, Nabuurs-Franssen MH, Schaper NC. International consensus and practical guidelines on the management and the prevention of the diabetic foot. Diabetes Metab Res Rev 2000;16:S84-92. [CrossRef]

8. Steed DL, Attinger C, Colaizzi T, Crossland M, Franz M, Harkless L, et al. Guidelines for the treatment of diabetic ulcers. Wound Repair Regen 2006; 14:680-92. [CrossRef]

9. Acosta JB, Savigne W, Valdez C, Franco N, Alba JS, del Rio A, et al. Epidermal growth factor intralesional infiltrations can prevent amputation in patients with advanced diabetic foot wounds. Int Wound 2006;3:232-9. [CrossRef]

10. Fernandez-Montequin JI, Infante-Cristia E, Valenzuela-Silva C, Franco-Perez N, Savigne-Gutierrez W, Artaza-Sanz H, et al. Intralesional injections of Citoprot-P (recombinant human epidermal growth factor) in advanced diabetic foot ulcers with risk of amputation. Int Wound J 2007:4:333-43. [CrossRef]

11. Buchberger B, Follmann M, Freyer D, Huppertz H, Ehm A, Wasem J. The importance of growth factors for the treatment of chronic wounds in the case of diabetic foot ulcers. GMS Health Technol Assess 2010;6:Doc12. [CrossRef]

12. Buchberger B, Follmann M, Freyer D, Huppertz H, Ehm A, Wasem $J$. The evidence for the use of growth factors and active skin substitutes for the treatment of non-infected diabetic foot ulcers (DFU): a health technology assessment (HTA). Exp Clin Endocrinol Diabetes 2011:119:472-9. [CrossRef]

13. MacNeil S. Progress and opportunities for tissue-engineered skin. Nature 2007;445:874-80. [CrossRef]

14. Lambrinos A, Chan B, Wells D, Holubowich C. Hyperbaric oxygen therapy for the treatment of diabetic foot ulcers: a health technology assessment. Ont Health Technol Assess Ser 2017:17:1-142. [CrossRef]

15. Shah JM, Omar E, Pai DR, Sood S. Cellular events and biomarkers of wound healing. Indian J Plast Surg 2012;45:220-8. [CrossRef]

16. Wetzler C, Kämpfer H, Stallmeyer B, Pfeilschifter J, Frank S. Large and sustained induction of chemokines during impaired wound healing in the genetically diabetic mouse: prolonged persistence of neutrophils and macrophages during the late phase of repair. J Invest Dermatol 2000;115:245-53. [CrossRef]

17. Cohen S. Isolation of a mouse submaxillary gland protein accelerating incisor eruption and eyelid opening in the new-born animal. $J$ Biol Chem 1962;237:1555-62. [CrossRef]
18. Pastore S, Mascia F, Mariani V, Girolomoni G. The epidermal growth factor receptor system in skin repair and inflammation. J Invest Dermatol 2008;128:1365-74. [CrossRef]

19. Gibbs S, Silva Pinto AN, Murli S, Huber M, HohI D, Ponec M. Epidermal growth factor and keratinocyte growth factor differentially regulate epidermal migration, growth, and differentiation. Wound Repair Regen 2000;8:192-203. [CrossRef]

20. Krishnan ST, Quattrini C, Jeziorska M, Malik RA, Rayman G. Neurovascular factors in wound healing in the foot skin of type 2 diabetic subjects. Diabetes Care 2007;30:3058-62. [CrossRef]

21. Acosta JB, del Barco DG, Vera DC, Savigne W, Lopez-Saura P, Guillen Nieto $G$, et al. The pro-inflammatory environment in recalcitrant diabetic foot wounds. Int Wound J 2008;5:530-9. [CrossRef]

22. Berlanga-Acosta J. Diabetic lower extremity wounds: the rationale for growth factors-based infiltration treatment. Int Wound J 2011:8:61220. [CrossRef]

23. Brown GL, Nanney LB, Griffen J, Cramer AB, Yancey JM, Curtsinger $L$ $3^{\text {rd }}$, et al. Enhancement of wound healing by topical treatment with epidermal growth factor. N Engl J Med 1989;321 (2):76-9. [CrossRef]

24. Esquirol-Caussa J, Herrero-Vila E. Human recombinant epidermal growth factor in skin lesions: 77 cases in EPltelizando project. J Dermatolog Treat 2019;30:96-101. [CrossRef]

25. Bhora FY, Dunkin BJ, Batzri S, Aly HM, Bass BL, Sidawy AN, et al. Effect of growth factors on cell proliferation and epithelialization in human skin. J Surg Res 1995;59:236-44. [CrossRef]

26. Wagner FW Jr. The dysvascular foot: a system for diagnosis and treatment. Foot Ankle 1981;2:64-122. [CrossRef]

27. Mustoe TA, Pierce GF, Morishima C, Deuel TF. Growth factor-induced acceleration of tissue repair through direct and inductive activities in a rabbit dermal ulcer model. J Clin Invest 1991;87:694-703. [CrossRef]

28. Nanney LB. Epidermal and dermal effects of epidermal growth factor during wound repair. J Invest Dermatol 1990;94:624-9. [CrossRef]

29. Cooper DM, Yu EZ, Hennessey P, Ko F, Robson MC. Determination of endogenous cytokines in chronic wounds. Ann Surg 1994;219:688-92. [CrossRef]

30. Zhang Y, Wang T, He J, Dong J. Growth factor therapy in patients with partial-thickness burns: a systematic review and meta-analysis. Int Wound J 2016;13:354-66. [CrossRef]

31. Marti-Carvajal AJ, Gluud C, Nicola S, Simancas-Racines D, Reveiz L, Oliva P, et al. Growth factors for treating diabetic foot ulcers. Cochrane Database Syst Rev 2015;(10):CD008548. [CrossRef]

32. Gomez-Villa R, Aguilar-Rebolledo F, Lozano-Platonoff A, Teran-Soto $J M$, Fabian-Victoriano MR, Kresch-Tronik NS, et al. Efficacy of intralesional recombinant human epidermal growth factor in diabetic foot ulcers in Mexican patients: a randomized double-blinded controlled trial. Wound Repair Regen 2014;22:497-503. [CrossRef]

33. Kahraman M, Misir A, Kizkapan TB, Ozcamdalli M, Uzun E, Mutlu M. The long-term outcomes following the application of intralesional epidermal growth factor in patients with diabetic foot ulcers. J Foot Ankle Surg 2019;58:282-7. [CrossRef]

34. Dumantepe M, Fazliogullari O, Seren M, Uyar I, Basar F. Efficacy of intralesional recombinant human epidermal growth factor in chronic diabetic foot ulcers. Growth Factors 2015;33:128-32. [CrossRef]

35. Tsang MW, Wong WK, Hung CS, Lai KM, Tang W, Cheung EY, et al. Human epidermal growth factor enhances healing of diabetic foot ulcers. Diabetes Care 2003;26:1856-61. [CrossRef] 
36. Park KH, Han SH, Hong JP, Han SK, Lee DH, Kim BS, et al. Topical epidermal growth factor spray for the treatment of chronic diabetic foot ulcers: a phase III multicenter, double-blind, randomized, placebocontrolled trial. Diabetes Res Clin Pract 2018;142:335-44. [CrossRef]

37. Yang S, Geng Z, Ma K, Sun X, Fu X. Efficacy of topical recombinant human epidermal growth factor for treatment of diabetic foot ulcer: a systematic review and meta-analysis. Int J Low Extrem Wounds 2016;15:120-5. [CrossRef]

38. Romero Prada M, Roa C, Alfonso P, Acero G, Huerfano L, Vivas-Consuelo D. Cost-effectiveness analysis of the human recombinant epidermal growth factor in the management of patients with diabetic foot ulcers. Diabet Foot Ankle 2018;9:1480249. [CrossRef]
39. Fernandez-Montequin JI, Valenzuela-Silva CM, Diaz OG, Savigne W, Sancho-Soutelo N, Rivero-Fernandez F, et al. Intra-lesional injections of recombinant human epidermal growth factor promote granulation and healing in advanced diabetic foot ulcers: multicenter, randomised, placebo-controlled, double-blind study. Int Wound J 2009:6:432-43. [CrossRef]

40. Aktaş Ş, Baktıroğlu S, Demir L, Kılıçoğlu Ö, Topalan M, Güven E, et al. Intralesional application of epidermal growth factor in limbthreatening ischemic diabetic foot ulcers. Acta Orthop Traumatol Turc 2016;50:277-83. [CrossRef]

\title{
ORIJINAL ÇALIŞMA-ÖZET
}

Turk J Surg 2020; 36 (1): 15-22

\section{İntralezyonal epidermal büyüme faktörü uygulaması diyabetik ayak ülseri iyileşmesine ve ampütasyonu önlemeye katkı sağlayan potansiyel bir tedavidir}

\author{
Ömer Arda Çetinkaya ${ }^{1}$, Süleyman Utku Çelik ${ }^{2}$, Miraç Barış Erzincan ${ }^{1}$, Barış Hazır ${ }^{1}$, Hakan Uncu ${ }^{1}$ \\ ${ }^{1}$ Ankara Üniversitesi Tıp Fakültesi, Genel Cerrahi Anabilim Dalı, Ankara, Türkiye \\ ${ }^{2}$ Gülhane Eğitim ve Araştırma Hastanesi, Genel Cerrahi Kliniği, Ankara, Türkiye
}

\section{ÖZET}

Giriş ve Amaç: Çalışmanın amacı, kronik diyabetik ayak ülseri (DAÜ) olan hastalarda intralezyonal epidermal büyüme faktörü (EBF) uygulamasının yara iyileşmesi üzerine etkisini ve ekstremiteyi majör ampütasyondan koruma etkinliğini araştırmaktır.

Gereç ve Yöntem: DAÜ olan 33 hasta Ocak 2013-Ocak 2017 tarihleri arasında intralezyonal EBF uygulaması ile tedavi edildi. Öncelikli amacımız, tedaviyi takip eden 12 ay içinde majör ampütasyonu önleme oranını belirlemekti. İkincil amaçlarımız ise EBF'nin ilk uygulamasından altı ay sonra $\geq \% 50$ granülasyon ile ülser yüzey alanının iyileşmesini ve altı ay sonra en az \%75 granülasyon ile gerçekleşen iyileşme oranını belirlemekti.

Bulgular: Üç hasta majör ilaç yan etkileri nedeniyle çalışma dışı bırakıldıktan sonra, toplam 30 (48 DAÜ) hastanın, 24 (37 DAÜ)'ünde EBF tedavisinin başlangıcından sekiz hafta sonra $\geq \% 50$ granülasyon elde edilirken, 6 (11 DAÜ) hastada istenilen düzeyde granülasyon sağlanamamıştır. Tedavinin altıncı ayında ise toplam 21 (31 DAÜ) hastada \%75 ve üzeri granülasyon oranı elde edilmiştir. Son olarak tedaviyi takip eden 12 . ayda bir majör ve yedi minör ampütasyon yapılırken beş hastada toplam 10 DAÜ'de iyileșme gösterilememiş, 17 hastada ise DAÜ tamamen düzelmiştir.

Sonuç: İntralezyonal EBF uygulamasının, iyi ayak bakımına ek olarak, DAÜ olan hastalarda olumlu sonuçları görülmektedir. Ayrıca, vasküler girişimlerin uygun olmadığı ve konvansiyonel yara bakımı yöntemleriyle iyileşmeyen DAÜ'lerde ekstremitenin ampütasyondan korunması ile ilgili umut verici sonuçlara sahiptir.

Anahtar Kelimeler: Ampütasyon, diyabetik ayak ülseri, epidermal büyüme faktörü

Doi: $10.5578 /$ turkjsurg.4541 